\title{
Co-Culture of a Methanogenic Archaeon and a Methanotrophic Bacterium on Sterilized Soil in Large Test Tubes: Design for Soil-Mediated Co-Culture
}

\author{
DAYÉRI DIANOU ${ }^{1}$ and KATSUKI ADACHI ${ }^{2 *}$ \\ ${ }^{1}$ Centre National de la Recherche Scientifique et Technologique (CNRST), BP 7047, Ouagadougou, Burkina \\ Faso \\ ${ }^{2}$ National Agricultural Research Center for Kyushu Okinawa Region, Department of Upland Research, \\ Miyazaki 885-0091, Japan
}

(Received May 14, 2001-Accepted September 3, 2001)

In a design utilizing a sterilized soil-mediated co-culture of methanogenic archaeon and methanotrophic bacterium, the activities of both the methanogen and methanotroph were examined. It was confirmed that $\mathrm{CH}_{4} \mathrm{was}$ produced by the methanogen after methanotrophic inoculation and suggested that this $\mathrm{CH}_{4}$ was oxidized by the methanotroph as the concentration of $\mathrm{O}_{2}$ increased, although emission of $\mathrm{CH}_{4}$ itself was indirect proof of $\mathrm{CH}_{4}$ oxidizing activity. On the other hand, in the control treatment, methanogenic inoculation without methanotrophic inoculation at different levels of $\mathrm{O}_{2}, \mathrm{CH}_{4}$ was not emitted (there was no activity to produce $\mathrm{CH}_{4}$ ). These results suggest a symbiotic relation in this co-culture system, because the methanogen provided $\mathrm{CH}_{4}$ to the methanotro$\mathrm{ph}$, while inoculation of the methanotroph was necessary for subsequent production of $\mathrm{CH}_{4}$ by the methanogen. The development of co-culture systems is essential for understanding the close relationship and interaction between methanogens and the methanotrophs in natural and agricultural environments.

Key words: co-culture, methanogenic archaeon, methanotrophic bacterium, paddy soil

Methane is an important warming gas whose atmospheric concentration has been increasing for decades ${ }^{9,21,34)}$. Methane emission is the net effect of $\mathrm{CH}_{4}$ production (methanogenesis) and oxidation (methanotrophy). Methanotrophic bacteria (methanotrophs) are obligately aerobic respiratory bacteria that utilize methane as a sole source of carbon and energy for growth ${ }^{8,17,29)}$ and hence, are considered important regulators of atmospheric methane fluxes in nature ${ }^{10,23)}$. Methanotrophs have been isolated from a variety of environments including freshwater lakes, wetlands, and the open ocean ${ }^{8,17-19,23,27,30,35)}$. In contrast, methanogenic archaea (methanogens) are strictly anaerobic archaea commonly isolated from natural anaerobic environments, including freshwater and marine sediments, wet and waterlogged soils, the

* Correspondence author; E-mail: kadachi@affrc.go.jp, Tel: +81986-22-1506, Fax: +81-986-23-1168 rumen of animals, and the gut of insects ${ }^{7,15,22)}$. Methanogens produce methane and provide it to methanotrophs, which utilize it as a source of energy. Consequently, there is considerable interest in the interaction between methanogens and methanotrophs with respect to $\mathrm{CH}_{4}$ production and oxidation in the interfaces of anaerobic and aerobic environments. Gerritse and Gottschal ${ }^{16)}$ established two-membered mixed cultures of a methanogenic archaeon and an aerobic bacterium in $\mathrm{O}_{2}$-limited conditions but mentioned that growth of Methanobacterium formicicum was markedly inhibited in the co-culture with Methylocystis species. Shen et al. ${ }^{32)}$ reported methanotroph and methanogen coupling in a granular biofilm under $\mathrm{O}_{2}$-limited conditions, although the coupling system included other aerobic and anaerobic bacteria. Hence the two-membered co-culture of a methanogen and a methanotroph is not well developed yet, although the two organisms are thought to interact closely with each oth- 
er in natural environments. The development of a model ecosystem with which to study production and oxidation of $\mathrm{CH}_{4}$ is essential for understanding the mechanism of $\mathrm{CH}_{4}$ emission from wetland paddy fields ${ }^{12,26)}$. Further, such a model should prove helpful in establishing techniques for the biological control of $\mathrm{CH}_{4}$ emissions from paddy fields, one of the major anthropogenic sources of $\mathrm{CH}_{4}$ emission to the atmosphere ${ }^{20,24,31,34)}$. This short report describes a soilmediated co-culture of methanogen and methanotroph using sterilized paddy soil.

\section{Materials and Methods}

Methanogenic and methanotrophic strains and preparation of inoculants

A methanotrophic strain, namely methanotroph isolate R16 (Methylosinus sp.) described by Dianou and Adachi ${ }^{11)}$, and a methanogenic strain, Methanobrevibacter arboriphilicus strain SA (=DSM7056, =JCM9315) isolated from paddy soil by Asakawa et $a l .{ }^{4}$, were used in this study. Inoculant solutions for co-culture of the methanotroph and methanogen were prepared in test tubes.

The methanotrophic strain R16 was grown in the nitratemineral-salts (NMS) medium described by Whittenbury et $a l .{ }^{11,35)}$, in a shaking culture at $30^{\circ} \mathrm{C}$. The liquid NMS medium $(5 \mathrm{ml})$ was dispensed into $34-\mathrm{ml}$ tubes then autoclaved. The tops of the tubes were sealed with $\mathrm{W}$-shaped butyl rubber stoppers. Then, $6 \mathrm{ml}$ of pure $\mathrm{CH}_{4}$ was passed through a $0.2 \mu \mathrm{m}$ pore filter syringe and injected into each tube to give about $18 \% \mathrm{CH}_{4}$ and about $16 \% \mathrm{O}_{2}$ in the head gas-phase. After inoculation, the tubes were incubated at $30^{\circ} \mathrm{C}$ with shaking. Growth was monitored by measuring optical density at $620 \mathrm{~nm}$ with a spectrophotometer (Hitachi U-2000), and $\mathrm{CH}_{4}$ oxidation was monitored by measuring the concentration of $\mathrm{CH}_{4}$ in the tube headspace with a gas chromatograph (Hewlett-Packard 5890A/II) equipped with a flame ionization detector and a glass column $(1.8 \mathrm{~m}, 2-\mathrm{mm}$ inner diameter) packed with Porapak R (50/80).

The methanogenic strain SA was grown in modified LPBM medium ${ }^{5)}$ which consisted of $\mathrm{KH}_{2} \mathrm{PO}_{4}(0.75 \mathrm{~g})$, $\mathrm{K}_{2} \mathrm{HPO}_{4}(0.75 \mathrm{~g}), \mathrm{NH}_{4} \mathrm{Cl}(1.0 \mathrm{~g}), \mathrm{MgCl}_{2} \cdot 6 \mathrm{H}_{2} \mathrm{O}(0.36 \mathrm{~g})$, trace mineral solution ${ }^{25)}(9 \mathrm{ml})$, vitamin mixture solution $\left.{ }^{6}\right)$ $(10 \mathrm{ml}), 2 \mathrm{~g} \mathrm{l}^{-1}$ resazurin $(0.5 \mathrm{ml})$, yeast extract $(0.5 \mathrm{~g}$, Difco), $\mathrm{NaHCO}_{3}(4.8 \mathrm{~g})$, L-cysteine hydrochloride $(0.5 \mathrm{~g})$ and $\mathrm{Na}_{2} \mathrm{~S} \cdot 9 \mathrm{H}_{2} \mathrm{O}(0.5 \mathrm{~g})$ in distilled water $(1,000 \mathrm{ml})$. The $\mathrm{pH}$ was adjusted to 7.0. The LPBM medium $(5 \mathrm{ml})$ was dispensed into 34-ml test tubes under $\mathrm{N}_{2}-\mathrm{CO}_{2}$ (4:1) gas-flushing, and the test tubes were sealed with $\mathrm{W}$-shaped butyl rubber stoppers. After autoclaving, the top gas phase was exchanged with an $\mathrm{H}_{2}-\mathrm{CO}_{2}(4: 1)$ atmosphere as growth substrate. After inoculation, the tubes were incubated at $30^{\circ} \mathrm{C}$ under static conditions. Cell growth (colony formation in the bottom of the liquid culture) was observed and $\mathrm{CH}_{4}$ production in the tube headspace was monitored by gas chromatography on day $0,15,23,30$ and 38 of incubation.

\section{Co-culture of a methanogen and methanotroph on steri- lized soil in 110-ml tubes}

The characteristics of the soil (paddy field soil) used in this experiment have been described ${ }^{1,28}$. The 110 -ml tubes with $30 \mathrm{~g}$ of $1 \mathrm{~mm}$-sieved soil were sterilized twice at $121^{\circ} \mathrm{C}$ for $1 \mathrm{~h}$ with a $24 \mathrm{~h}$ interval to eliminate the indigenous microflora. LPBM medium (40 ml) supplemented with $2 \mathrm{~g} \mathrm{l}^{-1}$ of $\mathrm{KNO}_{3}$ was then added under a $\mathrm{N}_{2}-\mathrm{CO}_{2}$ (4:1) gas atmosphere. The test tubes were sealed with rubber stoppers, and sterilized for $20 \mathrm{~min}$ at $121^{\circ} \mathrm{C}$. The gas phase was then exchanged and the tubes were filled with $\mathrm{H}_{2}-\mathrm{CO}_{2}$ (4:1) gas aseptically using a needle and a $0.2-\mu \mathrm{m}$-pore filter. After the mixing of the methanogen liquid culture (15-day-old culture) with a vortex mixer, aliquots $(4 \mathrm{ml})$ of the methanogenic strain SA culture were inoculated into the tubes and subsequently mixed with the soil solution using a vortex mixer, after which the tubes were incubated for 10 days at $30^{\circ} \mathrm{C}$. On the 10 th day of incubation, aliquots $(4 \mathrm{ml})$ of the methanotrophic strain R16 culture (7-day-old culture) were inoculated into the tubes, and serial amounts of pure $\mathrm{O}_{2}$ gas were injected, to give $0,2,5,10$ or $16 \% \mathrm{O}_{2}$ concentrations in the tube headspace. There were four replications. At approximately 10-day-intervals, headspace gas samples were taken and analyzed with the gas chromatograph described above.

\section{Results and Discussion}

For the preparation of inoculants of methanogen and methaotroph, methanotrophic strain R16 was grown in shaking cultures, and methanogenic strain SA in static cultures at $30^{\circ} \mathrm{C}$. Growth $(\mathrm{OD} 620 \mathrm{~nm})$ and $\mathrm{CH}_{4}$ oxidation (percentage of oxidized $\mathrm{CH}_{4}$ ) of methanotrophic strain $\mathrm{R} 16$ in about $18 \% \mathrm{CH}_{4}$ and about $16 \% \mathrm{O}_{2}$ is shown in Fig. 1. After 8 days incubation, optical density showed a maximum value and $98 \%$ of $\mathrm{CH}_{4}$ was already oxidized. Hence the 7day-old cultures were used as methanotroph inoculant in the co-culture experiment. Fig. 2 shows $\mathrm{CH}_{4}$ production of methanogenic strain SA in pure culture under static conditions. After 15 days incubation, cell aggregates of the strain in the bottom of the liquid culture were formed, and $\mathrm{CH}_{4}$ producing activity was high in the pure culture. The 15-day- 


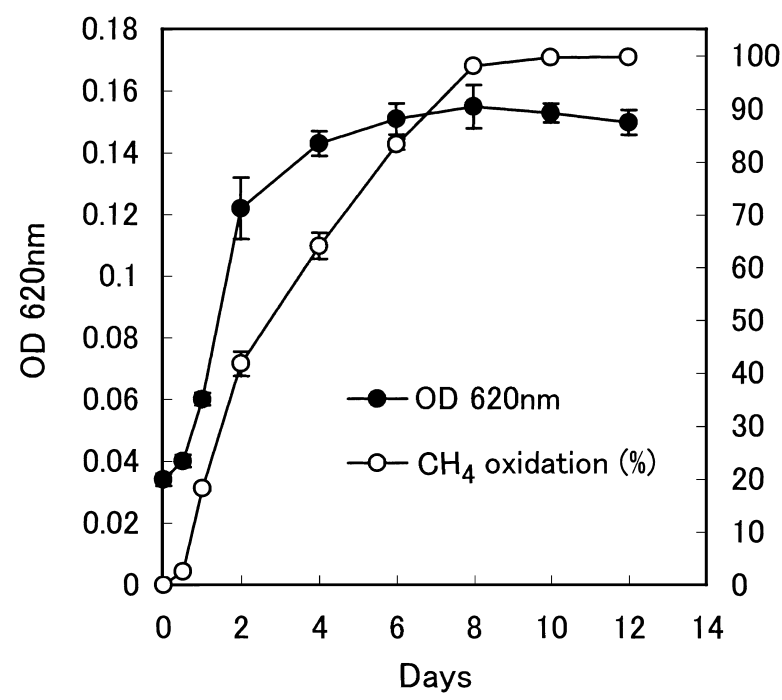

Fig. 1. Growth (OD $620 \mathrm{~nm}$ ) and $\mathrm{CH}_{4}$ oxidation (percentage of oxidized $\mathrm{CH}_{4}$ ) of a methanotrophic strain (Methylosinus sp. strain $\mathrm{R} 16)$ in a shaking culture in the presence of $18 \% \mathrm{CH}_{4}$ and $16 \% \mathrm{O}_{2}$ at $30^{\circ} \mathrm{C}$. Vertical bars show the standard deviations of three replications.

old cultures were used as methanogen inoculant.

In natural ecosystems such as waterlogged paddy soil microhabitats, where the partial pressure of $\mathrm{O}_{2}$ is very low even though the redox potential is high, anaerobic bacteria may be maintained ${ }^{14,33)}$. In our design, the use of sterilized soil was aimed to limit $\mathrm{O}_{2}$ toxicity for the methanogen in the co-culture as in a natural ecosystem.

Fig. 3 shows $\mathrm{CH}_{4}$ emission, namely the balance of $\left[\left(\mathrm{CH}_{4}\right.\right.$ production $)-\left(\mathrm{CH}_{4}\right.$ oxidation $)-\left(\mathrm{CH}_{4}\right.$ dissolved in the soil phase)], into the top gas phase in the system for soil-mediated co-culture. Thirty-six days after methanogen inoculation (26 days after methanotroph inoculation and $\mathrm{O}_{2}$ addition), a gradual $\mathrm{CH}_{4}$ emission was observed. The delay in emission may indicate that initial conditions were not suitable for methanogenic activity, even though the co-culture was set up with $\mathrm{N}_{2}-\mathrm{CO}_{2}$ (4:1) gas-flushing and the addition of reducing agents (L-cysteine hydrochloride $0.5 \mathrm{~g} \mathrm{l}^{-1}$ and $\mathrm{Na}_{2} \mathrm{~S} \cdot 9 \mathrm{H}_{2} \mathrm{O} 0.5 \mathrm{~g} \mathrm{l}^{-1}$ ). Among the 5 treatments with both methanogen and methanotroph, the highest $\mathrm{CH}_{4}$ emission was observed without $\mathrm{O}_{2}$, while the lowest emission was found at $16 \% \mathrm{O}_{2}$. The production of $\mathrm{CH}_{4}$ by the methanogen after methanotrophic inoculation was confirmed, and subsequent $\mathrm{CH}_{4}$ oxidation by the methanotroph along with increasing $\mathrm{O}_{2}$ concentrations was suggested, although the emission itself was indirect proof of $\mathrm{CH}_{4}$-oxidizing activity. On the other hand, in the control, i.e. methanogen inoculation without methanotroph inoculation at different levels of

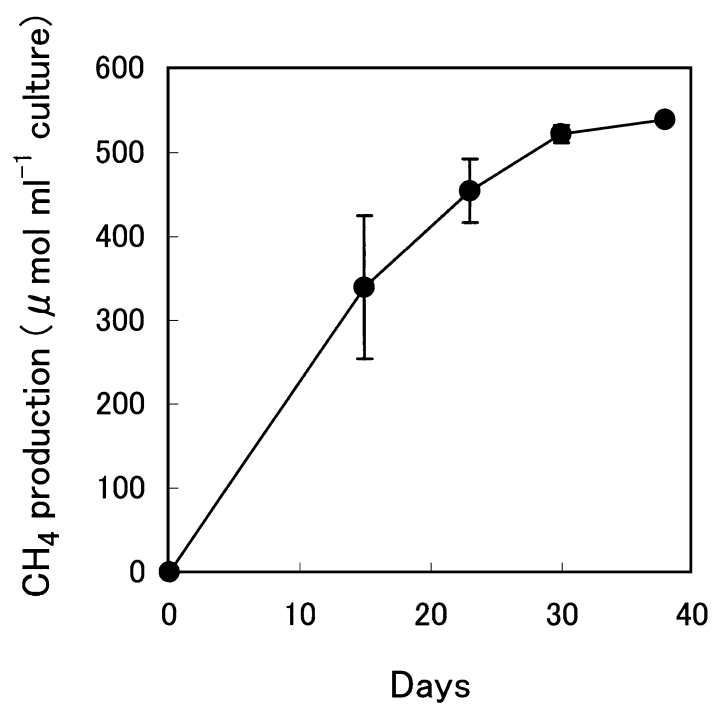

Fig. 2. $\mathrm{CH}_{4}$ production of a methanogenic strain (Methanobrevibacter arboriphilicus strain SA) in a static liquid culture at $30^{\circ} \mathrm{C}$. Vertical bars indicate the standard deviations of two replications.

$\mathrm{O}_{2}$, no emission of $\mathrm{CH}_{4}$ was observed (there was no activity to produce $\mathrm{CH}_{4}$ ).

These results suggest a symbiotic relation in this co-culture system, because the methanogen provided $\mathrm{CH}_{4}$ to the methanotroph, while the inoculation of methanotroph was necessary for subsequent production of $\mathrm{CH}_{4}$ by the methanogen. The activity of the methanotroph probably created anaerobic conditions in the soil suitable for methanogenic activity, protecting the methanogen from $\mathrm{O}_{2}$-toxicity. In natural environments, other aerobic bacteria or facultative anaerobic bacteria may play this kind of role (protection from $\mathrm{O}_{2}$-toxicity) for methanogens.

As Espiritu et al. ${ }^{13)}$ mentioned, the ecology (population fluctuations) of methanotrophs in paddy soil and rice rhizosphere is likely to be closely affected by the supply of $\mathrm{O}_{2}$, namely reduced or oxidative conditions, at each stage of rice cultivation. The studies of Amaral and Knowles ${ }^{2}$, and Amaral et al. ${ }^{3)}$ provide the foundations for the establishment of a promising new model ecosystem based on the twomembered co-culture of a methanogen and methanotroph for the study of the production, oxidation and emission of $\mathrm{CH}_{4}$ in paddy soil.

The authors also examined the effect of $\mathrm{O}_{2}$ concentrations on $\mathrm{CH}_{4}$ oxidation in the same system (mono-culture of the methanotroph), but relatively large standard deviations were obtained due to low replication numbers ( $\mathrm{n}=2$ or 3 ) (data not shown). Hence in future, elucidation of the effect of $\mathrm{O}_{2}$ concentrations on $\mathrm{CH}_{4}$ oxidation in mono-cultures of methan- 


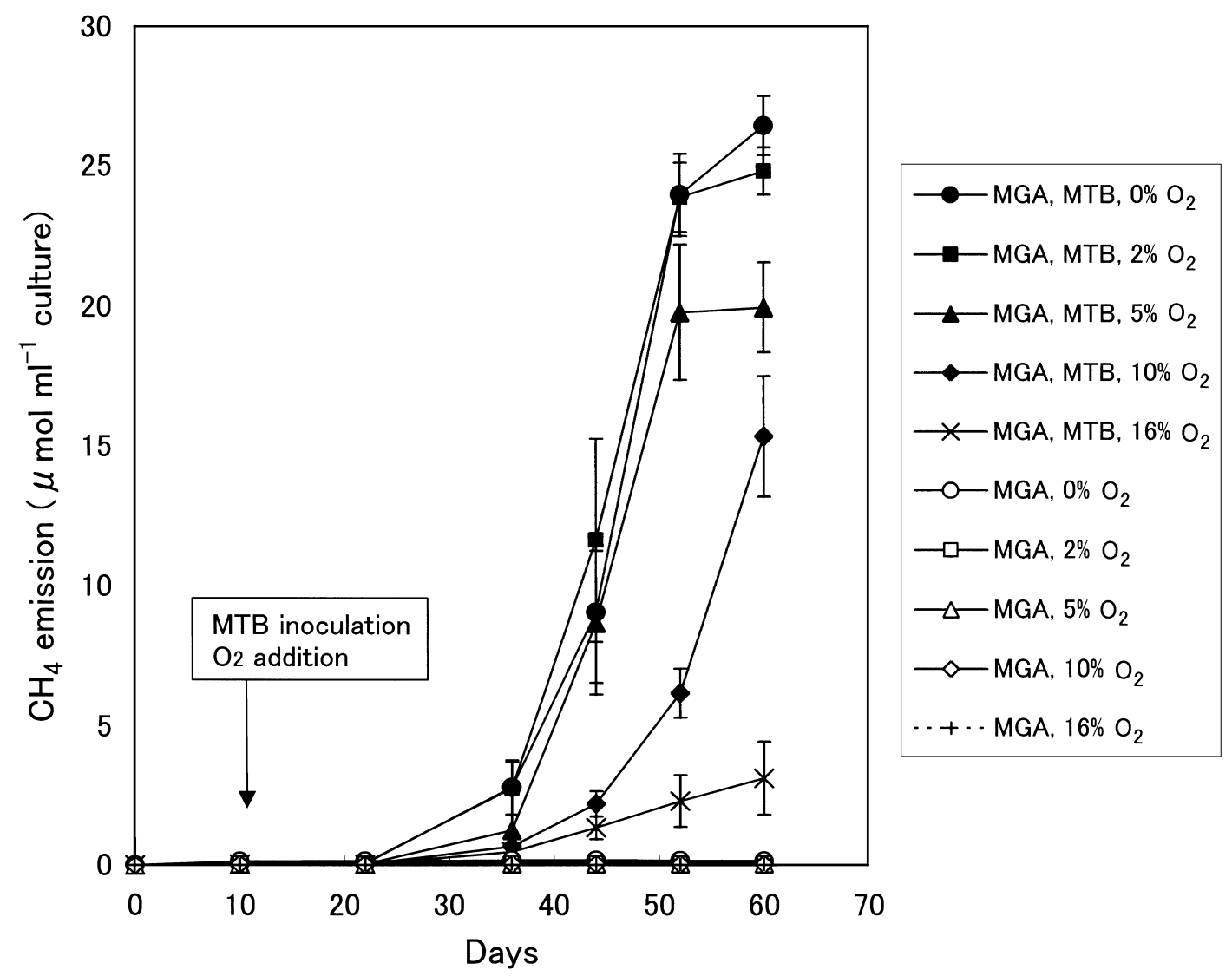

Fig. 3. Effect of methanotroph inoculation at different concentrations of $\mathrm{O}_{2}$ in the presence of methanogen on $\mathrm{CH}_{4}$ emission into headspaces in soil-mediated co-cultures. Vertical bars show the standard deviations of four replications. MGA, methanogenic archeon, Methanobrevibacter arboriphilicus strain SA; MTB, methanotrophic bacterium, Methylosinus sp. strain R16. In the 5 treatments with MGA and without MTB at different concentrations of $\mathrm{O}_{2}, \mathrm{CH}_{4}$ concentrations in the headspaces were very low (within the range of 0.03 to $0.17 \mu \mathrm{mol} \mathrm{ml}^{-1} \mathrm{culture}$ solution $\pm<0.02)$ throughout the incubation period.

otrophs and enumeration of the methanogen and methanotroph in co-cultures from the onset to the end of the incubation period is necessary to confirm the methanotrophic capacity and the establishment of both microbes. This short report shows that we are still in the preliminary stages of developing a co-culture-system for methanogens and methanotrophs with which to estimate the activity of $\mathrm{CH}_{4}$ production and oxidation, because the soil-mediated design was too simple. Further experiments are required for the establishment of an improved model ecosystem based on the co-culture of a methanogen and methanotroph with or without soil-mediation.

\section{Acknowledgements}

The authors are grateful to Drs. N. Maeno, K. Minami, T. Yamashita, S. Yashima and T. Hayashi, Japan International Research Center for Agricultural Sciences (JIRCAS), for their support. They also thank Dr. S. Asakawa, Nagoya University, for providing the methanogen, Methanobrevibacter arboriphilicus strain SA. This study was funded by JIRCAS.

\section{References}

1) Adachi, K., W. Chaitep and T. Senboku. 1997. Promotive and inhibitory effects of rice straw and cellulose application on rice plant growth in pot and field experiments. Soil Sci. Plant Nutr. 43: 369-386.

2) Amaral, J.A. and R. Knowles. 1995. Growth of methanotrophs in methane and oxygen counter gradients. FEMS Microbiol. Lett. 126: $215-220$.

3) Amaral, J.A., C. Archambault, S.R. Richards and R. Knowles. 1995. Denitrification associated with groups I and II methanotrophs in a gradient enrichment system. FEMS Microbiol. Ecol. 18: 289-298.

4) Asakawa, S., H. Morii, M. Akagawa-Matsushita, Y. Koga and K. Hayano. 1993. Characterization of Methanobrevibacter arboriphilicus SA isolated from a paddy field soil and DNA-DNA hybrid- 
ization among M. arboriphilicus strains. Int. J. Syst. Bacteriol. 43: 683-686.

5) Asakawa, S. and K. Hayano. 1995. Populations of methanogenic bacteria in paddy field soil under double cropping conditions (rice-wheat). Biol. Fertil. Soils 20: 113-117.

6) Balch, W.E., G.E. Fox, L.J. Magrum, C.R. Woese and R.S. Wolfe. 1979. Methanogens: Reevaluation of a unique biological group. Microbiol. Rev. 43: 260-296.

7) Bouwman, A.F. 1990. Soils and the greenhouse effect. John Wiley \& Sons, New York.

8) Bowman, J.P., L. Jiménez, I. Rosario, T.C. Hazen and G.S. Sayler. 1993. Characterization of the methanotrophic bacterial community present in a trichloroethylene-contaminated subsurface groundwater site. Appl. Environ. Microbiol. 59: 2380-2387.

9) Crutzen, P.J. 1995. On the role of $\mathrm{CH}_{4}$ in atmospheric chemistry: Sources, sinks and possible reductions in anthropogenic sources. Ambio 24: 52-55.

10) Denier van der Gon, H.A.C. and H.U. Neue. 1996. Oxidation of methane in the rhizosphere of rice plants. Biol. Fertil. Soils 22: 359-366.

11) Dianou, D. and K. Adachi. 1999. Characterization of methanotrophic bacteria isolated from a subtropical paddy field. FEMS Microbiol. Lett. 173: 163-173.

12) Dianou, D., B.M. Espiritu, K. Adachi and T. Senboku. 1997. Isolation and some properties of methane-oxidizing bacteria from a subtropical paddy field. Soil Sci. Plant Nutr. 43: 735-740.

13) Espiritu, B.M., K. Adachi and T. Senboku. 1997. Effect of application of rice straw and cellulose on methane emission and biological nitrogen fixation in a subtropical paddy field. III. Populations of methane-oxidizing bacteria in soil and rice rhizosphere. Soil Sci. Plant Nutr. 43: 729-734.

14) Furusaka, C., Y. Nagatsuka and H. Ishikuri. 1991. Survival of sulfate-reducing bacteria in oxic layers of paddy soils, p. 259266. In W.S. Fyfe (ed.), Developments in geochemistry, Vol. 6, J. Berthelin (ed.), Diversity of environmental biogeochemistry, Elsevier, The Netherlands.

15) Garcia, J.-L. 1990. Taxonomy and ecology of methanogens. FEMS Microbiol. Rev. 87: 297-308.

16) Gerritse, J. and J.C. Gottschal. 1993. Two-membered mixed cultures of methanogenic and aerobic bacteria in $\mathrm{O}_{2}$-limited chemostats. J. Gen. Microbiol. 139: 1853-1860.

17) Hanson, R.S., A.I. Netrusov and K. Tsuji. 1992. The obligate methanotrophic bacteria Methylococcus, Methylomonas, and Methylosinus, p. 2350-2364. In H. Balows, H.G. Trüper, M. Dworkin, W. Harder and K.H. Schleifer (ed.), The procaryotes, 2nd ed., Springer-Verlag, New York.

18) Hanson, R.S. and E.V. Wattenberg. 1991. Ecology of methylotrophic bacteria, p. 325-348. In I. Goldberg and J.S. Rokem (ed.), Biology of methylotrophs, Butterworth-Heinemann, Boston.

19) Holzapfel-Pschorn, A., R. Conrad and W. Seiler. 1985. Production, oxidation and emission of methane in rice paddies. FEMS Microbiol. Ecol. 31: 343-351.
20) IPCC-Intergovernmental Panel on Climate Change 1992. Climate change: The supplementary report to the IPCC scientific assessment, J.T. Houghton, B.A. Callender and S.K. Varney (ed.), Cambridge Univ. Press, Cambridge.

21) Khalil, M.A.K. and R.A. Rasmussen. 1990. Atmospheric methane: Recent global trends. Environ. Sci. Technol. 24: 549-553.

22) Mah, R.A. and M.R. Smith. 1981. The methanogenic bacteria, p. 948-977. In M.P. Starr, H. Stolp, H.G. Trüper, A. Balows and H.G. Schlegel (ed.), The prokaryotes, Vol. 1, Springer-Verlag, Berlin.

23) Mancinelli, R.L. 1995. The regulation of methane oxidation in soil. Annu. Rev. Microbiol. 49: 581-605.

24) Minami, K. and H.U. Neue. 1994. Rice paddies as a methane source. Clim. Change 27: 13-26.

25) Morii, H., M. Nishihara and Y. Koga. 1983. Isolation, characterization and physiology of a new formate-assimilable methanogenic strain (A2) of Methanobrevibacter arboriphilus. Agric. Biol. Chem. 47: 2781-2789.

26) Nouchi, I. 1995. What is the mechanism of methane release from rice paddies to the atmosphere? Kagaku to Seibutsu (Chem. Biol.) 33: 560-563 (in Japanese).

27) Omelchenko, M.V., L.V. Vasilyeva and G.A. Zavarzin. 1993. Psychrophilic methanotroph from tundra soil. Curr. Microbiol. 27: 255-259.

28) Oyediran, G., K. Adachi and T. Senboku. 1996. Effect of application of rice straw and cellulose on methane emission and biological nitrogen fixation in a subtropical paddy field. I. Methane emission, soil-ARA, and rice plant growth. Soil Sci. Plant Nutr. 42: 701-711.

29) Roslev, P. and G.M. King. 1994. Survival and recovery of methanotrophic bacteria starved under oxic and anoxic conditions. Appl. Environ. Microbiol. 60: 2602-2608.

30) Saralov, A.I., I.N. Krylova, E.E. Saralova and S.I. Kusnetsov. 1984. Distribution and species composition of methane-oxidizing bacteria in lake water. Microbiology 53: 695-701.

31) Sass, R.L. 1994. Short summary chapter for methane, p. 1-7. In K. Minami, A. Mosier and R. Sass (ed.), $\mathrm{CH}_{4}$ and $\mathrm{N}_{2} \mathrm{O}$ : Global emissions and controls from rice fields and other agricultural and industrial sources, Yokendo, Tokyo.

32) Shen, C.F., C.B. Miguez, D. Bourque, D. Groleau and S.R. Guiot. 1996. Methanotroph and methanogen coupling in granular biofilm under $\mathrm{O}_{2}$-limited conditions. Biotechnology Letters 18: 495500.

33) Wakao, N. and C. Furusaka. 1976. Presence of micro-aggregates containing sulfate-reducing bacteria in a paddy-field soil. Soil Biol. Biochem. 8: 157-159.

34) Wassmann, R., H. Papen and H. Rennenberg. 1993. Methane emission from rice paddies and possible mitigation strategies. Chemosphere 26: 201-217.

35) Whittenbury, R., K.C. Phillips and J.F. Wilkinson. 1970. Enrichment, isolation and some properties of methane-utilizing bacteria. J. Gen. Microbiol. 61: 205-218. 